\title{
National identity and nationalism in New Year's speeches of French presidents
}

\author{
LONNEKE VAN NOIJE and ELLEN HIJMANS
}

\section{Abstract}

In many European countries the question of cultural identity has gained special importance due to the increase of globalization, the position of the United States, and the European unification. How can political leaders deal with these developments without alienating their people? In what ways do they express national identity in popular communication? Is nationalism a characteristic of their rhetoric? These questions are asked in regard to thirty-six New Year's speeches held by the last five French presidents. By answering these questions we will develop a perspective on the concepts of national identity and nationalism.

Discourse analysis shows a typical discourse for every president, in which nationalist rhetoric appears to play a role. Above all, differences between three structures of significance, or frames, are distinguished, which can be described as 'sense of belonging' or 'paternal protection', 'the myth of French values', and 'the significant other'.

Keywords: national identity, nationalism, presidential speeches, qualitative content analysis, European integration

\section{Introduction}

In this article we will address the discursive construction of national identity in contemporary France. All over the world people identify, to a greater or lesser degree, with the nations they belong to, and cherish feelings that are more or less nationalistic. A recent development faced by the both the Western world and France that has turned national identity into a pressing matter is the opening of the national borders. One of the reasons for this development is the unparalleled export of American cultural goods. According to many this is an indication for the distribution of American mass culture at the expense of original cul- 
tures: Le défi américain [the American challenge] (Schlesinger, 1991: 141; Schiller, 1969). As a counterbalance, a number of European countries opened up their national borders. Cooperation could give Europe more of an edge on the global market and could also be a means to secure European identity. On the other hand, open borders could just as well increase the vulnerability of national identity. Political leaders must keep perceptions of the population in line with present developments as well as with their policy to protect national autonomy as much as possible. Thus, similarities between the ideas of the leaders and those of the population will be stressed, while divergent facts and feelings must be accommodated.

This development is crucial for the way in which France has managed its national identity and nationalistic feelings. Recently, the European Union has taken a great step forward by creating a monetary union which raises the question whether European cultural diversity will be able to survive. It can be expected that individual nations will keep their distance on the issue of cultural unification. In this respect, the French are no exception, and France has regularly raised its voice in defending its cultural identity. Although France has always been a great advocate of the European Union, the French are also known as a chauvinistic people and the preservation of national identity is highly ranked on the French political agenda. An illustration of the particular importance France attaches to decision making based on its own system of values can be found in its recent resistance to the United States in preparation of operation 'Iraqi Freedom'. France used its veto right in the Security Council and made it impossible for the European Union to present a collective and unanimous judgment. Although Germany sided with France on this occasion, the French attitude provoked fierce indignation and annoyance among the Americans, to the extent that 'French fries' were renamed 'Freedom fries'.

The attention to French identity is especially of great importance for the national unity of a people that has originally been brought together more by history than by ethnic relations. Nationalistic revivals have always originated from a cultural rather than a racial ideology, with the exception of Le Pen and his extreme right-wing movement (Meyer and Geschiere, 1999: 10). Internal differences in France are great, as Chaunu (1982: 371) aptly expresses. National identity serves to transcend internal differences: "We have the weakness to believe that what concerns us, concerns all men. In the difficult art of living together, we have learned to mimic conflicts, to simulate a civil war in order to avoid it" [our translation $]^{1}$.

Hence, the question of national identity currently presents a number of European member states, France in particular, with a paradox. Two 
interests are at stake: Encouragement of a vigorous and legitimate Europe, and recognition of collective national attainments. In order to gain support for the European cause among the peoples of Europe and to enhance the willingness to cooperate on this supranational level, it is important that national executives reassure the survival of their own familiar cultural and spiritual heritage in the communication to their public. Through this acknowledgement of one's national identity, the fear for attachment to a European identity may dissolve. However, if the experience of national identity is emphasized to such a degree that it starts to resemble nationalism, the significance of a European people will hardly progress beyond a monetary union.

To gain knowledge about the French national identity and nationalism as communicated by the ones responsible for guiding this powerful European country into the future, we have analyzed the New Year's speeches of the presidents of the Fifth Republic of France, from 1958 up to 2000. In a cumulative qualitative content analysis of these speeches we first identified the discourse referring to national identity and secondly the discourse related to nationalism. Finally, we reconstructed frames of cultural meaning that underlie the discursive construction of national identity and nationalism. This enabled us to reach a conclusion about the significance of nationalism in the public communication of presidents to the French people.

\section{The concepts of national identity and nationalism}

The concepts of national identity and nationalism are notoriously complex, as is the relation between them. Analytically, the concept has still not been formulated unambiguously, but it is certain that national identity carries a strong emotional dimension. People often irrationally value objects and traditions that symbolize the unity and identity of a nation. Likewise, nations strive for the security of cultural authenticity and political autonomy, inspired by the alliance that a considerable part of the population experiences towards the nation and each other. These feelings can be understood as the awareness of national identity, a notion that can be put into words or otherwise remain on an emotional level. Because of its opaque nature, we will approach the basic idea of national identity and nationalism in the context of New Year's speeches of French presidents as 'sensitizing concepts' (Glaser and Strauss, 1967). This means that we will consider these concepts as provisional concepts that are empirically elaborated during analysis. Our analysis is guided to specific aspects of the phenomenon by relevant findings of other researchers, as will be explained below. 


\section{National identity}

The origin of emotional solidarity between a nation and a people is still unknown. We think that national identity provides people with a place in the world; i. e., through collective identity one comes to know oneself as a group member and as an individual. When one feels at home and belongs in a group, uncertainties about one's life are reduced to manageable proportions. The idea that people share the same fate may relieve the burden on the shoulders of an individual. From a constructionist point of view, the world is seen as the product of human signification, or culture, and national identity is one of the cultural aspects with which this is accomplished.

Inspired by three relevant investigations by De Cillia, Reisigl, and Wodak (1999), Smith (1991), and Triandafyllidou (1998), we will first designate the main characteristics of national identity. De Cillia et al. (1999) developed five semantic macro-areas in relation to the discursive construction of Austrian identity and nation: "(1) The idea of a 'homo austriacus' and a 'homo externus' (2) the narrative of a collective political history (3) the discursive construction of a common culture (4) the discursive construction of a collective present and future and (5) the discursive construction of a "national body" (158). We adapted these areas to the French situation by distinguishing 'homme français' and 'homme étranger' to denote the idea of an 'internal' or 'indigenous' French identity and an 'external' or 'foreign' other identity.

Smith (1991: 14) delineates the conditions for a national identity to develop in the following definition of a nation: "A named human population sharing a historic territory, common myths and historical memories, a mass, public culture, a common economy and common legal rights and duties for all members".

The work of De Cillia et al. and Smith underlines the concrete, basic conditions of a nation and its culture. Nevertheless, we think that it takes more than a piece of land or a group for a national identity to emerge. What is missing is the aforementioned sense of solidarity and mutual connection. Although De Cillia et al. mentioned the 'homo externus', or 'other', they do not fully elaborate on the role of the other and the emotional dimension. Triandafyllidou (1998) expands this emotional aspect of identity as 'a sense of belonging'. She cites Connor (1978), who attributes the irrational, affective and psychological sense of connection between fellow group members to a shared belief of common descent. Evidently, this is not very likely, but what counts is that people believe in it and in daily life recognize each other as being the same.

Without this emotional component, national identity would be less valuable to the population because identification with the nation would 
not occur. For this to happen, the feeling must be present that this home base, this history, this culture, this economy, this scenery, and so forth are unique for this population. If one identifies with these attainments, the awareness emerges that this is at the core of mutual connection. However, at the same time its complement arises, namely the recognition that in being connected one is distinct from outsiders. Triandafyllidou contends that in this dual process of inclusion and exclusion the constructive contribution of 'the other' must be taken into account. To get to know oneself as a nation, one needs comparison with the other.

In other words, national identity has a double nature. As an inner directed inclusive process, it consists of shared group characteristics that provide people with a sense of belonging. As an outer directed process it stresses those elements that demonstrate differences with others, who, by being different, are excluded. Hence, the experience of difference is essential for the development of national awareness, as is the sense of belonging.

In some cases, so-called 'significant others' can leave an even heavier imprint on the experience of national identity. This is the case if, in one way or another, these others posit a threat to a nation. Threats originate from outside, from adjacent territories that exert pressure on the frontiers and autonomy of the nation, or from inside, from specific groups within a nation sharing a culture. In the latter case nations confront the risk of witnessing a deterioration of what makes them unique (Triandafyllidou, 1998: 600).

This approach of identity as a dual process, both inward and outward looking, matches our affinity with a more general symbolic interactionist view on identity, which centers on a dialectical construction of identity (Mead, 1934; Hijmans, 2003). Although Triandafyllidou does not refer to this social psychological approach, she uses a similar way of conceptualizing the double nature of national identity. Thus, we applied this concept of 'a sense of belonging' and 'the significant other' to the French context. French presidents may well have experienced a threat from other nations or groups that motivated them in their attempt to form or transform French national identity in their New Year's speeches. During the Fifth Republic, France has known a considerable amount of crises. Although French territory with its present frontiers has not been under fire, it may well be the case that France has felt enough threats to its cultural identity to overtly challenge a real or imagined significant other.

\section{Nationalism}

In view of the above-mentioned, nationalistic feelings will especially come to the fore in times of tension, when feelings of alliance grow stronger 
and the need for authorities to activate the national cultural frame of reference, or national identity, becomes more urgent. It is important to note that these attitudes can be nationalistic without being extreme. Unfortunately, nationalism and extremism are often conflated. Instead, we suggest, in accordance with Smith, the qualification of the connection of national identity and nationalism, by making clear what the differences between the two are. Nationalism is: "An ideological movement for attaining and maintaining autonomy, unity and identity on behalf of a population deemed by some members to constitute an actual or potential nation" (Smith, 1991: 73). The individual passive feeling of alliance, a characteristic of national identity, can develop into an explicit desire for collective action. In this way nationalism becomes a social movement, grounded upon an ideology, aimed at realizing autonomy, unity, or identity.

Including identity as a distinct element in the definition of nationalism clarifies that they represent two separate concepts. In addition to Smith, Schlesinger (1991) views nationalism as a form of culture, as an ideology with its own language, mythology, symbol system and consciousness. In this way nationalism is able to express and intertwine these three ideals into its discourses. Discourse is a powerful instrument because it articulates ideology in concrete words and formulations. By bringing national identity to life as an ideal it becomes clear, tangible, and comprehensible for every individual of the population. Direct emotions and nationalistic sentiments are being played on in discourse, as is the passive consciousness of national identity that is subsequently (re)created according to nationalistic goals. Thus, national identity underlies nationalism, but in a later stage national identity is also the product of nationalism. One could say that nationalism reinvents identity (Smith, 1991: 92); it reinforces and actualizes it. Nationalism uses this renewed identity as a point of reference of its ideological discourse. Appropriate symbols and elements of history will be selected to create an ideal national identity (Schlesinger, 1991: 168-172), which is also known as the invention of culture. The cultural frame of reference of a people is not so much a natural fact, but rather imposed by socialization, mainly through education and the media (Smith, 1991: 16).

Nationalism is most effective when it operates from a central point within the nation. Nationalists' ideals are highly political: Freedom of the people by realizing (or maintaining) an independent state. It follows that central political authorities often take an interest in and are in a most suitable position for the mobilization of the people. Political leaders might therefore use nationalist discourses, since one of the ways they maintain power is by the 'invention of culture'. We consider the New 
Year's speeches of French presidents as means of political communication that may be effective as a conduit for socialization and contribute to the extent of nationalistic national identity.

\section{The speeches}

We analyzed New Year's speeches of all the French presidents ${ }^{2}$ of the Fifth Republic, from 1958 to $2000^{3}$. This amounts to a total of 36 speeches held by five presidents, the complete population except for Mitterand's second term ${ }^{4}$. The total number of paragraphs analyzed amounts to $224^{5}$.

New Year's speeches are ideal research material for our analysis. First of all, it is only on this one occasion during the year that the president is expected to address the whole of the population, irrespective of differences in class and political preferences (Finniss-Boursin, 1992: 18-19). The president will enter French living rooms at $8.00 \mathrm{pm}$, regardless of economic or political circumstances. This makes it a very homogenous research corpus, as well as a de-politicized moment. The strength of the New Year's speeches lies in their symbolic function. Historically, the French have always perceived their president as not just the head of state, but also as leader of the nation and thus expect him to present himself accordingly. The symbolic office he holds makes him the one whose words have power over France's destiny, and so his wishes avert misfortune and inspire prosperity (Finniss-Boursin, 1992).

Secondly, the content of the speeches is not prescribed, but they deal with a general evaluation of the past as well as constructing an outlook to the future. Financial and other policy technicalities are omitted in favor of general terms. The president is given the opportunity to write a speech according to his personal preferences, therefore a profusion of subjectivity may be expected. He does not speak on behalf of his government, but on behalf of the only man who holds the real power, namely himself. This is possible due to the institutional changes carried out by President De Gaulle (Elgie and Griggs, 2000). Although on many occasions leaders make use of their personal communication experts to write eloquent speeches for them, the New Year's speeches have always been taken very seriously by the presidents since their personal competences as a leader are at stake. It is therefore certain the speeches spring from their own minds (Finniss-Boursin, 1992: 18-19). The head of state will seize the opportunity to convey values and sentiments that he deems important for the French people. If he is out to express nationalistic values, they will certainly be picked up in this type of speech. 


\section{Research design}

In addition to the already mentioned discourse analytical approach used by De Cillia et al., we will also utilize the concept of framing to deal with textual and thematic characteristics of mediated messages. Entman (1993) and Scheuffele (1999) consider framing as a form of agenda setting on a second level. This approach contends that the subjects that people think about do not matter as much as the packaging that contains the message; the structure of the story, and the technology used to convey it. Therefore, we first of all created an inventory of the defining themes of national identity and nationalism addressed by the presidents' speeches (see Figure 2). Secondly, we also took note of the wording, key, and tone in which these themes were framed, to reconstruct underlying meaning structures. Our approach to national identity and nationalism as sensitizing concepts is directly related to the interpretative approach to qualitative content analysis in media research (Hijmans, 1996). This means that an inductive and comparative analysis is performed that will show which characteristics of national identity and nationalism have been demonstrated by the presidents' speeches (see the criteria in the coding instrument). The coding instrument is thus partly the product of the analysis.

\section{Research instrument}

In developing a coding instrument we integrated work by De Cillia et al. (1999) and Smith (1991), and complemented it with the concept of 'the significant other' as used by Triandafyllidou (1998). Due to the interrelation of national identity and nationalism, our coding procedure comprised several cumulative steps. Because not all expressions refer to national identity or nationalism, the first logical step is to identify relevant expressions that contain allusions to a French identity (see Figure 1). These expressions were selected for further analysis.

We also accounted for the complex relationship between national identity and nationalism. As mentioned earlier, national identity is both a concept by itself, as well as one of the three elements that refer to nationalism. In a second step, the expressions selected earlier are analyzed using the three criteria we developed comparatively to assess whether expressions contain a neutral, more innocent idea of national identity, or imply a normative form of nationalism. As in all forms of qualitative content analysis, the context determines when the president's rhetoric goes beyond the boundary between the awareness of national identity and nationalism. Whatever the qualification (neutral versus normative) may be, the various entrances for national identity within 


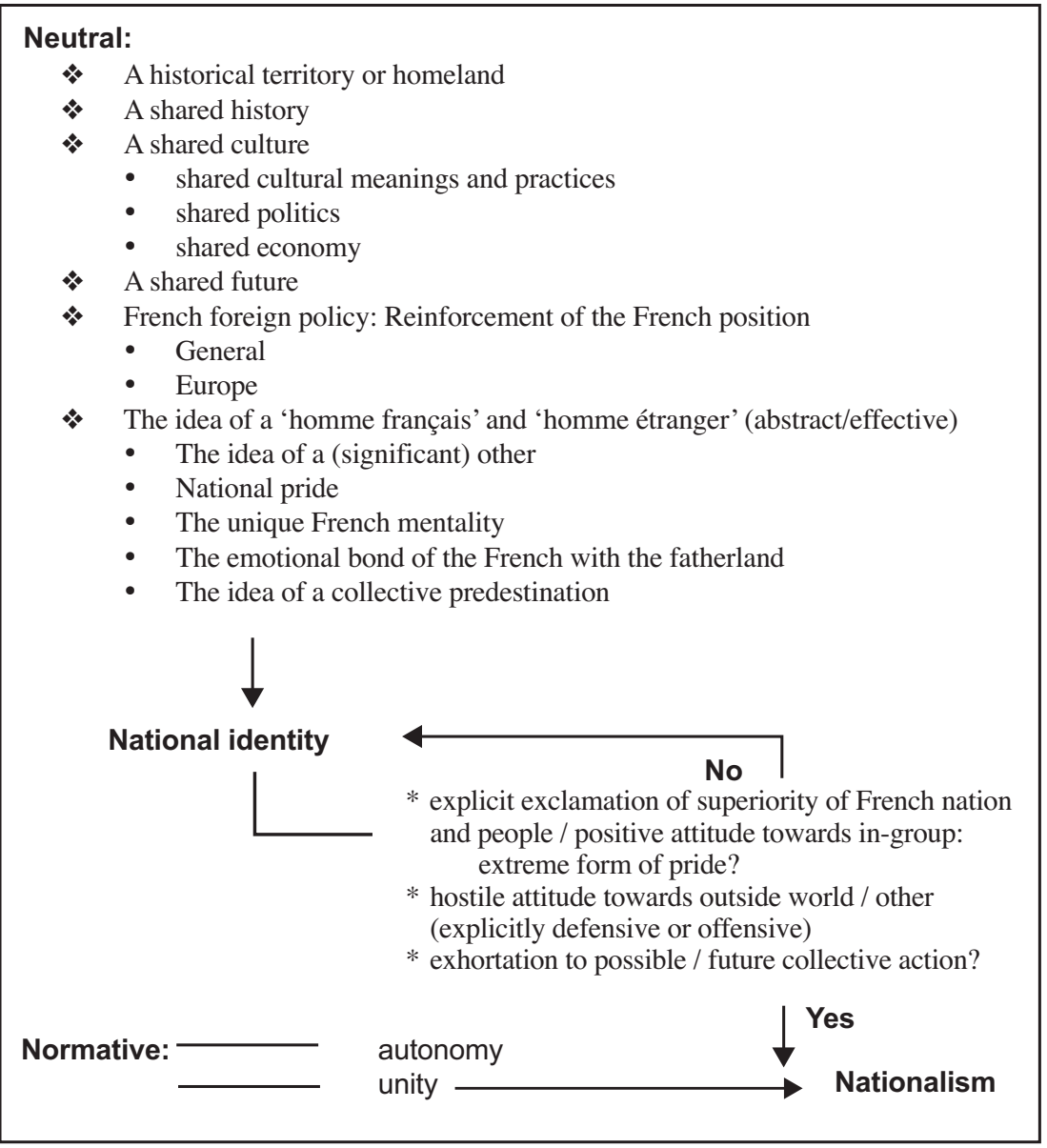

Figure 1. Coding instrument national identity/nationalism.

the instrument (step one) not only tell us whether national identity is being touched upon or reinvented, but also which register of sentiment or knowledge is used for its activation. This substantive information is then used in the third step to uncover the frames that the presidents deem essential to 'Frenchness'.

Earlier in this article, we clarified our definition of nationalism. We coded an expression as nationalistic in three cases. First, whenever there was reference to the ideals of national autonomy, unity, and national identity. We explained that the qualification of references to national identity as neutral or nationalistic relies upon three criteria which were 
tested in the second step. First, the portrayal of one's own nation not just as positive, but as invincible and superior to elements from the outside world (criterion 1). Invincibility as a value counts as an extreme perception of the in-group. The second criterion is the opposite of the first one; i. e., whenever expressions were used to show negative others more or less as the incarnation of evil (criterion 2). Certainly, a negative other can be used to justify one's own actions, to emphasize the need for solidarity, etc. However, criterion 2 refers to a depiction of the other as an aim in itself, as a threat or undesirable condition that needs to be defeated by the in-group. Third, to realize its ideals a social movement depends upon the mobilization and mass support of the people. Whenever words are intended to inspire the people to immediate or future (mental) mobilization, we coded this as nationalism (criterion 3).

This last criterion is applied very broadly, because it is not very likely that this type of speeches intends to instigate the French to real action. The 'call for mobilization' is considered a contribution to an atmosphere in which nationalistic sentiments can thrive by evocating people to demonstrate an active mental commitment towards an event.

\section{Units of analysis}

Every New Year's speech contains several themes. Therefore, a speech is not a single meaningful whole with a beginning and end, but consists of several meaningful parts. An expression or a specific key in the opening is not necessarily relevant for other parts. In identifying units of analysis it is important to respect contextual information, that is, linguistic and thematic meaningful interactions (Krippendorff, 1980: 57-60). The president has, so to speak, his own agenda of themes, covered by paragraphs. We maintain this thematic logic, because themes maintain their own relation with national identity and/or nationalism, and offer specific possibilities for the president to refer to these concepts. In practice, we first analyzed the linguistic characteristics (key, tone, and wording) of every sentence in a sequence of paragraphs. Interpretation could only proceed after examination of the context of these characteristics. The paragraph is the best logical contextual unit for the sentence, the recording unit.

\section{Results}

Despite our expectations of finding evidence for an evolution of France into a strong advocate of the European cause, we discovered no meaningful historical trends in the development of themes that refer to national identity, or in the two remaining core concepts of nationalism, autonomy and unity. Our thematic analysis of the speeches shows that 

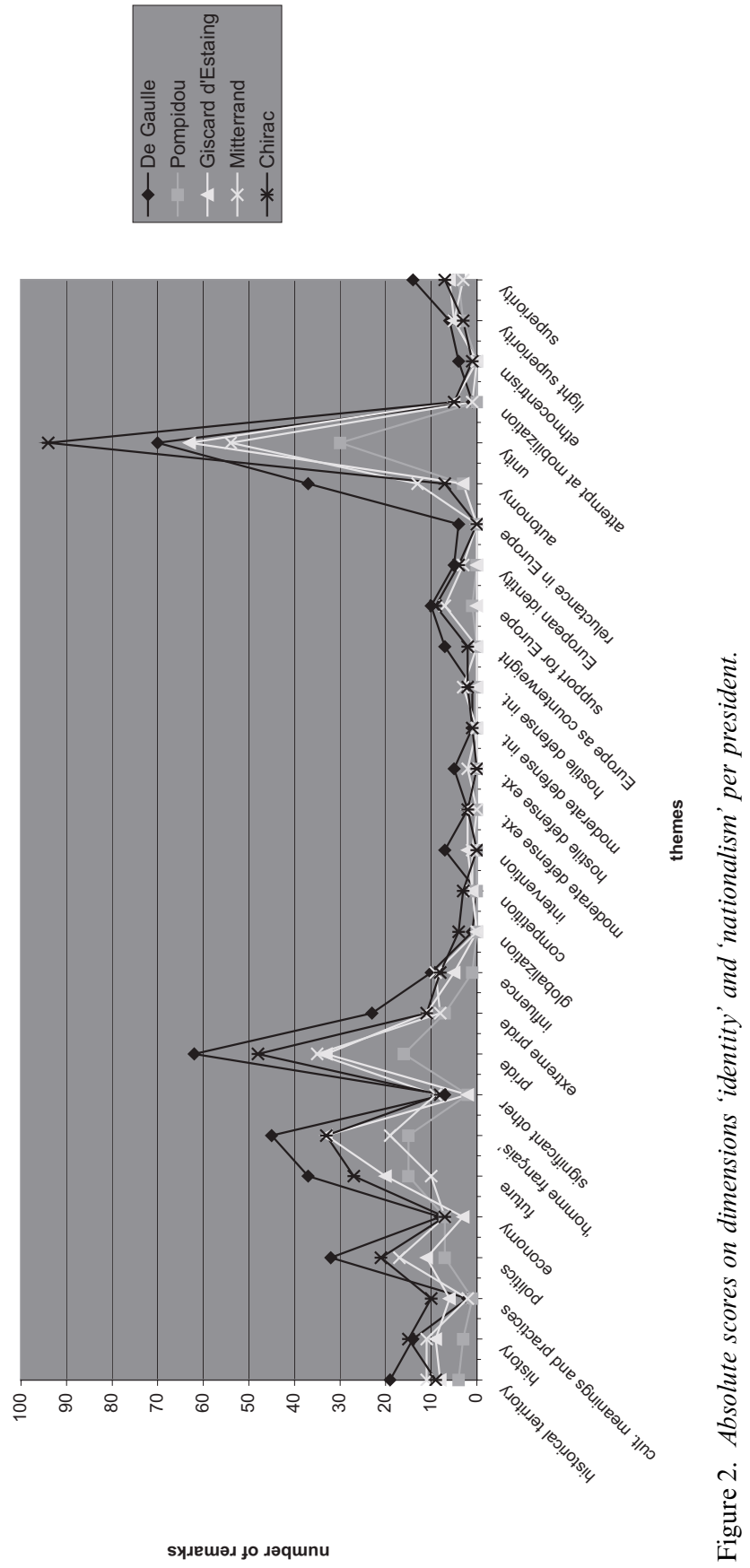
the attention given to the various elements of identity or nationalism fluctuates with the arrival of every new president. The themes highlighted depend on the individual rather than on the period in time. Figure 2 presents the presidents' overall attention to all themes, in absolute number of times they were referred to.

Below we present our findings in regard to the first two research questions: 'How are the ideals of national identity, autonomy, and unity constituted' and 'Can the rhetoric be qualified as nationalistic?'. We will illustrate the typical characteristics of the speeches for each president individually, but comparatively. Quotations are to be read as mere illustrations of our findings, not as proof.

\section{Charles de Gaulle (1958-1969)}

De Gaulle's rhetoric meets each of the three basic criteria of nationalism, that is to say, national awareness or identity, autonomy, and unity. For the main part the speeches are dedicated to protect French autonomy from threatening ideological domination of the Soviet Union and from cultural-economical domination of the United States. The Soviet Union is considered to pose the greatest and most direct threat to the entire world. The following quotation gives a striking example of how De Gaulle tries to convince his people of France's power to resist this superpower, which he portrays as the enemy.

Although the Soviet Empire has colonized 40 million Asian Muslims and enslaved as twelve foreign peoples, it is still not satisfied, and continues to encourage and exploit possible turbulence, so that it can obtain a foothold in troubled countries. In short, we will not be paralyzed by such a malicious agitation. [Malgré l'Empire soviétique, qui, non content de coloniser 40 millions de Musulmans asiates, et d'asservir une bonne douzaine de peuples qui lui sont complètement étrangers, encourage et exploite toutes les secousses afin de prendre pied dans les pays troublés. Bref, nous ne nous laisserons pas paralyser par cette odieuse agitation] (1960, par. 4) ${ }^{6}$.

This nationalistic ideal of autonomy is reinforced by wrapping it up in expressions of extreme pride and by providing an explicit external enemy. Closely related is his choice of possibilities offered by national identity. His interest in this area is almost completely focused on enlarging the prestige of France. De Gaulle wants power and justifies it using sentiments of extreme pride. According to him, France deserves international respect because it is the only country that has a mission of exerting 
this influence for the benefit of the world, as is illustrated in the quotation below:

In the name of good sense, of our attachment to Indochina, and of the two centuries of friendship that we have maintained with America, we think it necessary that America ends this trial by withdrawing its forces back to its own grounds. On the day, however far away, that America decides to do so, our country could, with all its heart, open the doors through which would pass world peace, aid to backward peoples, and fraternity of mankind, all things which France, in line with its calling, champions today. [Au nom du bon sens, de l'attachement que nous gardons à l'Indochine, de l'amitié deux fois séculaire que nous portons à l'Amérique, nous tenons pour nécessaire que celleci mette un terme à l'épreuve en amenant ses forces sur son sol. Du jour, si lointain qu'il soit, où elle déciderait cela, notre pays pourrait, - et de quel cœur! - s'employer à faire ouvrir toutes grandes les portes par ou passeraient la paix mondiale, l'aide aux peuples retardés et les fraternités des hommes dont, suivant sa vocation, il est aujourd'hui le champion] (1966, par. 5).

His attention to the three ideals of nationalism seems rather exhaustive, and his presentation of the themes concerned is unsurpassed in the dosage of extreme pride, that is to say, of feelings of superiority. It is also unsurpassed in its display of hostility towards significant others. In the example below he informs the people that an advanced armament is indispensable if France wants to take a bold stand against approaching menaces to protect its autonomy:

First of all, we must continue the effort that will provide us with thermonuclear weapons, whose unique power is an adequate answer to the threat of aggression and consequently the only power that grants us independence. [Il faut d'abord que nous poursuivions l'effort qui doit nous doter d'un armement thermonucléaire, le seul dont la puissance soit adéquate à la menace d'une agression et le seul, par conséquent, qui nous permette l'indépendance ] (1963, par. 8).

One could say that, of all the presidents, De Gaulle's speeches make the greatest contribution to a possible evocation of nationalism, because he indulges more than any other president in expressions that cross the boundary between national awareness and nationalism. Nevertheless, his attempts towards mobilization are negligible, and thus for this criterion the conclusion does not hold. 


\section{Georges Pompidou (1969-1974)}

Even though every president has his own particularities, Pompidou takes up a rather exceptional position. Strange as this may sound, a lack of items characterizes his speeches. At first glance, this becomes apparent through the limited length of his speeches, which precludes any extensive exposition on a deeper level. Our analysis revealed furthermore that the contents of his words linger on the surface. He would rather speak in general terms than go into details. But let it be understood that nationalism can just as well be nourished with general terms. Therefore, analysis of how this president turned to his people is still worthwhile. However, the quest for national identity and nationalism showed once more that the succession of De Gaulle by Pompidou equals a change from one extreme to another. Except for President Mitterrand, he has the least need to express any form of extreme national pride; moreover, the other two criteria of nationalism are entirely absent. He does not convey any idea of a possible enemy and does not bother to unchain enthusiasm for present or future collective action. The only time he mentions the outside world is when he seeks affirmation of economic and social successes of France. According to this president, France remains invincible in these areas and it is here that it may recover its 'grandeur', as the following quotation shows:

Hardly a year ago I said to you: "We are not the richest, but we count among the happiest. It is enough to look around us". Well, today, it is enough to listen to the voices of the foreign commentators, English, American, or Russian, to realize that the situation in France is appreciated by all and envied by many. Let us not be vain because of this, but let us acknowledge it and further, let us not ease up on our efforts because of this success. [Il y a un an, je vous disais encore: "Nous ne sommes pas les plus riches, mais nous sommes parmi les plus heureux. Il suffit de regarder autour de nous". Or, aujourd'hui, il suffit d'écouter la voix des commentateurs étrangers, qu'ils soient Anglais, Américains ou Russes, pour apprendre que la situation de la France est appréciée par tous et enviée par beaucoup. N'en tirons pas vanité, et non plus, mais reconnaissons-le et puis n'essayons pas de nous endormir sur le succès] (1971, par. 3).

His nationalism is concentrated in a rather modest way on striving for unity, but mostly on aspects of national identity. Pompidou values national economy and politics and, as said, finds satisfaction in the victory of France in the international competition. His texts may activate nationalistic sentiments among the people, but even then their appeal is one-sided and not very insisting. 


\section{Valéry Giscard d'Estaing (1974-1981)}

Both national unity and identity are put forward by Giscard d'Estaing to stimulate nationalism and they are couched with a considerable emotional charge. Like Pompidou, he does not want to burden the French by confronting them with too many serious issues on this special evening of the year. Therefore he chooses to stay close to home. Autonomy does not play any part whatsoever. Likewise, we did not detect any hostile attitude towards internal or external 'others'. As for extreme pride or feelings of superiority we find him in the middle section, and he stands out for his rousing language, meant to instigate the people to (mentally) mobilize themselves.

Sometimes people interrogate me on the occasion of a press conference, or an interview, and they ask me: "What does France mean to you?" To me, France, it is the best there is in the world, because of its scenery and because of its people. [Parfois on m'interroge à l'occasion d'une déclaration, d'une interview, et on me demande: "Pour vous, la France, qu'est-ce que c'est?" Pour moi, la France, c'est ce qu'il y a de meilleur dans le monde, à cause de son paysage et à cause de son peuple] (1974, par. 5).

With similar expressions of pride he conveys an unbreakable sense of confidence to the people. This answers the question whether his rhetoric qualifies as nationalistic in a positive way. His pride and his attempts to call for mobilization aim at two clearly marked areas: The French people and French values. These two constitute the story lines of his speeches. In paying compliments to the people he hardly shows any reservations. The next quotation is one of many in which the people are the object of the expression of nationalism:

But little by little, we are restoring our situation. Why? Because we are dealing with the French and I would like to say a word about you. On account of my function as president of the Republic, I meet other leaders and I am proud to represent the French. They are a serious and courageous people, as they have shown during the energy crisis. They possess great faculties of adaptation and it is precisely because of this that they should not be crushed under bureaucratic constraints or formalities. When necessary, they are a generous people and they have proven it when dealing with the refugees from Southeast Asia. They are also a people that possess an instinct of its unity in dangerous circumstances. [Mais peu à peu nous rétablirons notre situation. Pourquoi? Parce qu'il s'agit des Français et je voudrais dire un mot sur vous. Moi qui, du fait de ma fonction de Président de la République, rencontre les autres dirigeants, je suis fier de représenter les Français. 
Ce sont des gens sérieux et courageux, comme ils viennent de la démontrer face à la crise de l'énergie. Ils ont de grandes facultés d'adaptation et c'est pourquoi il ne faut pas les écraser sous les contraintes ou les formalités bureaucratiques. C'est un peuple généreux quand il le faut, et qui vient de le démontrer vis-à-vis des réfugiés du Sud-Est asiatique. C'est aussi un peuple qui, dans les circonstances dangereuses, a l'instinct de son unité] (1979, par. 6).

France has a lot to offer to the world when it comes to civilization, freedom, humanity and other values belonging to the heritage of the French Revolution of 1789.

We have been everywhere in your name this year [...], everywhere we have come across the radiance of France. [...] May it remain, in our tormented and violent universe, a beacon of liberty and of the reconciliation of men. This, I wish for France and for the world. [Partout où nous sommes allés cette année en votre nom [... partout nous avons rencontré le rayonnement de la France. [...] Puisse-t-elle, dans notre univers tourmenté et violent, rester le phare de la liberté et du rapprochement entre les hommes. Je le souhaite pour elle et pour le monde] (1975, par. 3).

In this example France is portrayed as a beacon of freedom and reconciliation, an obvious reference to the 'enlightened' French mentality and the desire to spread it out throughout the world. To conclude, Giscard d'Estaing is, above all, convinced of the self-worth of his nation. As we will show with Chirac, nationalism on these issues could be characterized as extraordinary.

\section{François Mitterand (1981-1987/1995)}

The speeches of Mitterand try to make us believe that the age of 'soft' politics has disappeared with his arrival. The French will have to get used to a more 'Gaullist' approach. The goal-orientated father and statesman replaces the idea of the older brother. The people need to be taken care of, but should not be spared and certainly not patronized. In short, the first left-wing president denounces the soft approach of the velvet glove. In spite of their different political orientations, Mitterand resembles general De Gaulle, not only because of his communicative strategy, but also because of the issues that draw his attention. Thus, at first sight, Mitterand succeeds in imitating De Gaulle, although it could be an unconscious result of the course of history. Only one theme proves worthy of his attention: French autonomy. The pressing threat he perceives, especially from outside, is translated into an undeniable hostile attitude. 
First of all towards the Soviet Union, who tries to deprive the world of its freedom, and on some occasions towards the Americans who seem to develop dominance in all other areas. These actions qualify both of them as implied significant others.

But why should we speak of France without looking around us? 1983 will see the two superpowers prepare or over-arm themselves on European soil. I stick to this golden rule: Balance of forces in the world, and in Europe, is the most certain road to wisdom. Peace and balance will be the policy of France in any case, as a counter point to all the roughhousing. [Mais pourquoi parler de la France sans regarder autour de nous ? 1983 verra, sur le sol de l'Europe, les deux superpuissances s'arranger ou surarmer. Je m'en tiens à cette règle d'or: L'équilibre des forces dans le monde et en Europe est la plus sûre invitation a la sagesse. Paix, équilibre, telle sera en tout cas, dans cette rude partie qui s'engage, la politique française] (1982, par. 8).

The quotation above shows how Mitterrand intends to arm France against these threats by reinforcing its influence, which again is based on the age-old French mentality of reason and humanity. This is almost the only context in which he seems to find references to the national identity worthwhile. The same holds true for his references to national unity; they occur only to attain this end, as is the case in the following example in which he reminds the people of their courage and asks support for his independent defense policy:

Outside, the dangers accumulate. A country like France has known for over a million years that history belongs to courageous people and that the sacred love for the fatherland lives there. That is why, in the light of our alliance, we must assure ourselves of our own defense. [Au dehors, les périls s'accumulent. Un pays comme la France sait depuis plus de mille ans que l'histoire appartient aux peuples courageux et qu'habite l'amour sacré de la Patrie. C'est pourquoi, dans le cadre de notre alliance, nous devons assurer nous-mêmes notre défense (1981, par. 4)].

Without any doubt, Mitterand is trying to create a climate for nationalism, although his scores on autonomy and the creation of an enemy do not equal those of De Gaulle. Moreover, no one is as reserved as Mitterand, clothing the message to the French people with sentiments of extreme national pride. Just like the case of Giscard d'Estaing, we discovered obvious traces of nationalism in his speeches, but they were found in a restricted domain. Where nationalism of Mitterand ends, the nationalism of Giscard d'Estaing begins. 


\section{Jacques Chirac (1995-)}

Without any doubt the speeches of president Chirac could be characterized as a nationalistic discourse with many interests. Chirac seems to unite the preferences and agendas of his predecessors. All nationalist ideals pass in review, but only the messages of unity and identity are conveyed with a corresponding discourse. He attains high scores on the scale of extreme national pride, particularly on feelings of superiority. De Gaulle is the only one to surpass him in this respect. The object of these feelings is the French people with all its achievements, its heritage and its values. This is illustrated in the quote below:

We are the heirs of a long history. We live in a free, even an envied country. A country that has endured a lot of trials but that has created a strong identity for itself. It means a lot to be French. It is about rights that should be preserved. It is about duties which should be fulfilled. The stronger your willpower, the greater your mobilization, the further we shall come, and the more powerful France shall be. [Nous sommes les héritiers d'une longue histoire. Nous vivons dans un pays libre, envié même. Un pays qui a traversé bien des épreuves, qui s'est forgé une identité forte. Ce n'est pas rien que d'être Français. Ce sont des droits qu'il faut préserver. Ce sont des devoirs qu'il faut assumer. Plus ferme sera votre volonté, plus grande sera votre mobilisation, plus loin nous irons. Plus forte sera la France] (1995, par. 12).

Like Giscard d'Estaing he experiences an extraordinary feeling of selfworth that he wants to use for improvement of the world. He assures the people that he shall do everything in his power to secure the French identity. Chirac thinks it too valuable to endanger and besides, France still has an important part to play in the world. France has preserved its grandeur in its international performance and the people must be convinced of this fact. He attempts to do so with the help of expressions like the ones below:

... And nevertheless they will be the signal of progress if we not only know how to master, but more importantly, how to humanize and civilize globalization. This struggle for a more human world where law and brotherhood prevail is France's fight. It is my fight. We are perfectly capable of succeeding because we will do it together. Together we will change the era. [... Et pourtant ils seront porteurs de progrès si nous savons non seulement les maîtriser, mais surtout si nous savons humaniser, civiliser la mondialisation. Ce combat pour un monde plus humain où doivent prévaloir le droit et la fraternité est celui de la 
France. C'est le mien. Nous sommes tout à fait capables de réussir parce que nous le ferons ensemble. C'est ensemble que nous allons changer l'époque ] (1998, par. 3).

Or:

Yes, our country brings a message. A message of fraternity, tolerance, and justice. This is how I see France. France looks its past in the eye, the bad times as well as the good times. France is loyal to its history, to its values, and is determined to defend them. A nation that enters the future with confidence because it has chosen progress and solidarity. [Oui, notre pays est porteur d'un message. Un message de fraternité, de tolérance et de justice. C'est ainsi que je vois la France. Une France qui regarde en face son passé, les heures sombres comme les heures glorieuses. Une France fidèle a son histoire, a ses valeurs, et décidée à les défendre. Une nation qui entre dans l'avenir avec confiance, parce qu'elle a choisi le progrès et la solidarité] (1995, par. 12).

His many attempts to mobilize his compatriots are very characteristic. If one adds this criterion to the role of extreme pride in his speeches, this yields the qualification of a president whose discourse is very suitable to evoke nationalism. Thus, De Gaulle places first and Chirac is a runnerup, in spite of their different interests. It is important to note that Chirac is clearly internationally orientated, but sees no reason to feel threatened and thus to maintain a suspicious or hostile position towards anyone. On the contrary, he encourages the French to accept the challenge and participate in the new openness of the world. In that context the next example sheds some light on his attitude towards European integration:

Together we have chosen to make France grow within Europe. Europe guarantees us peace. Europe grants us greater value in the world. [Nous avons choisi ensemble de faire grandir la France dans l'Europe. Une Europe qui nous garantit la paix. Une Europe qui nous permet de peser d'avantage dans le monde ] (1999, par. 6).

In spite of his nationalistic discourse he manages to present himself as a generous president in European matters'.

\section{Recapitulating}

The analysis of the first two research questions has shown that every individual president stirs a nationalistic chord. The following figures illustrate presidential preferences for types of discourse in which a crite- 


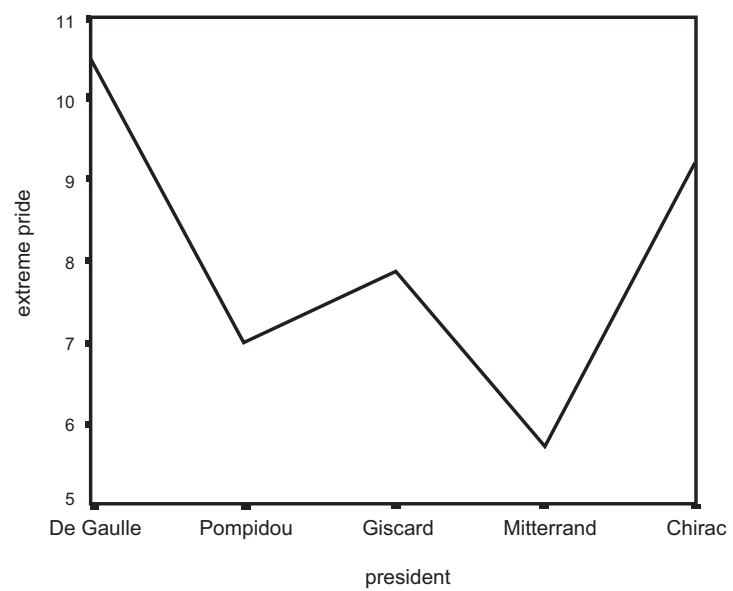

Figure 3. Weighted scores of the presidents on the criterion 'extreme national pride'.

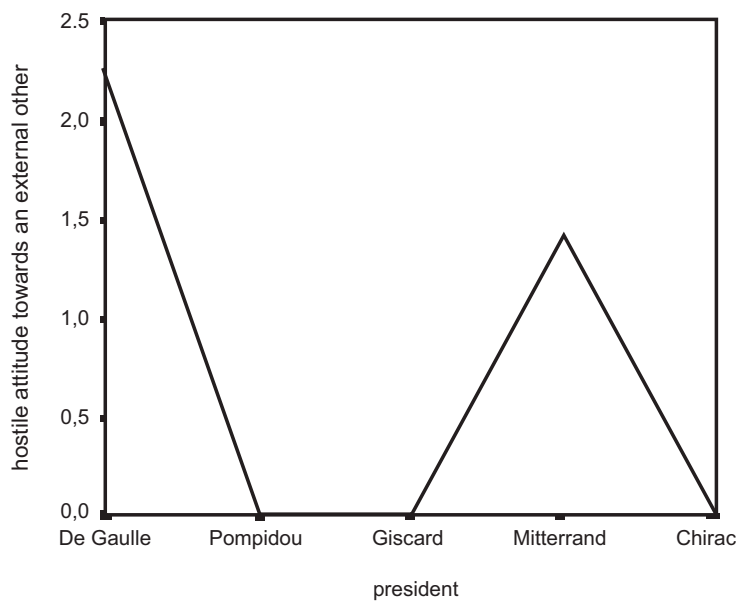

Figure 4. Weighted scores of the presidents on the criterion 'hostile attitude towards an external 'other'.

rion of transition from the neutral national identity to a more normative nationalism is satisfied. To assure that the scores are comparable, they have been weighted for each president according to the number of speeches they have produced.

Yet, it should be clear that we are dealing with a rather innocent kind of nationalism, meant to create an atmosphere of optimism and motivation among the people, and not to cut France off from the rest of the 


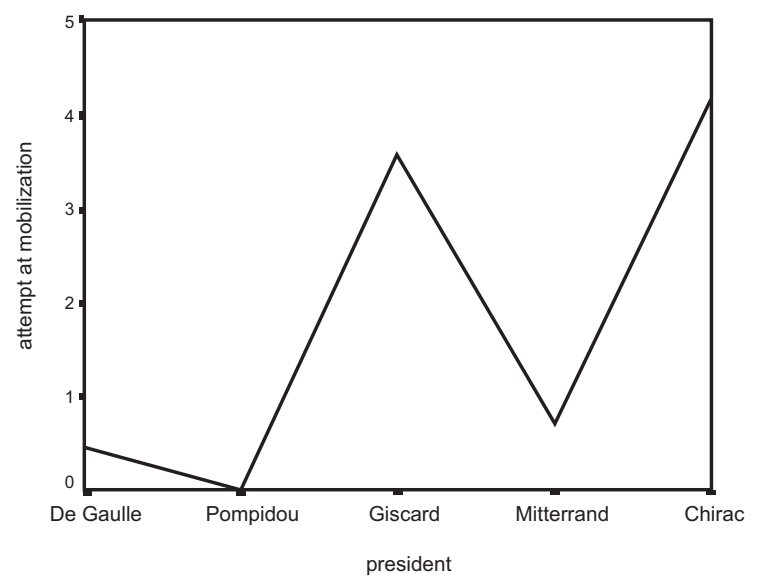

Figure 5. Weighted scores of the presidents on the criterion 'incentive for mobilization or activation of the national identity'.

world or to attain French world domination, as has been proven by the course of history. As said before, we would therefore like to disengage this form of nationalism from a ready association with extremism. Thus, there is no apparent reason to conclude that we witnessed an unambiguous culture or shared tradition of nationalism in speeches of French presidents. There were simply too many changes in tone and style of nationalism with every succeeding president. Moreover, contrary to our expectations we discovered no development or continuity in themes; nationalism turned out to be independent from the presidents' political preferences. These sentiments appeared to be alive on the right wing as well as on the left wing of the political arena. Paradoxically, the very president who embodies 'Gaullism' or the right, De Gaulle, and the only socialist president, Mitterrand, showed striking similarities, especially regarding the object of their nationalism: The autonomy of the French nation, which is of primary concern to both of them.

The topicality of the central problem has been illustrated in the introductory paragraph by two phenomena: Globalization; i.e., the hegemony of America, and the integration of Europe. The research material perfectly covers the period in which these developments crystallized. In advance we accounted for the fact that these changes could possibly radiate an important incentive for a strong national or nationalistic awareness, because the French could feel threatened by it. However, our analysis shows that American hegemony recurred indeed to some extent, but not as prominently as we expected. The United States and their culture were depicted less as the undeniable enemy than the Soviet Union, 
which was portrayed as the great malefactor in the discourses of both De Gaulle and Mitterrand. We encountered major interest in the power of the United States only in the speeches of president Chirac. As said before, he will do anything to protect French culture, and above all he shows a positive attitude towards globalization to boost French economy and prestige. On top of this we conclude that French presidents, converse to the reputation they hold on this subject, are mainly concerned with winning public support for the integration of Europe. Mitterrand leads the way in associating the name of France with the European Union:

My third wish will be quickly said: "Happy new year to Europe", so that today's youth will be able to enter the next century without any problem. We French have the right to be proud. Thirty years ago, two of us invented the European Community. And it was again with us, at Fontainebleau last June, that Europe regained its self-awareness. People speak of grand projects for the young, well, here we have one! Yes, happy new year to Europe. [Mon troisième vœu sera vite dit: "Bonne année pour l'Europe", afin que la jeunesse d'aujourd'hui puisse entrer de plain-pied dans le siècle prochain. Nous avons le droit d'être fiers, nous, Français. Ce sont deux des nôtres qui, voici trente cinq ans, ont inventé l'Europe de la Communauté. Et c'est encore chez nous, à Fontainebleau, au mois de juin dernier, qu'elle a repris conscience d'elle-même. Puisqu' on parle de grands projets pour la jeunesse, en voilà un. Oui, Bonne Année pour l'Europe] (1984, par. 3).

It is true that Mitterand and De Gaulle both convince the people of their determination to keep an eye on European plans and safeguard the interests of France. This way they seem to reinforce public support. Even allusions to a European identity are sometimes made as a possible image of the future of France, to which they are willing to lend their assistance. De Gaulle expresses this briefly and to the point using the following words:

[We want to] Help to construct Europe by bringing together its nations. Europe can and must be the greatest political, economical, military, and cultural power that ever existed for the benefit of the people. [Aider à construire l'Europe, qui, en confédérant ses nations, peut et doit être, pour le bien des hommes, la plus grande puissance politique, économique, militaire et culturelle qui ait jamais existé] (1960, par. 5).

French identity must be guarded at all costs from uniformity within Europe. But at the same time, the European identity will have to be 
established to protect Europe and all its members from the uniformity that results from the globalization under supervision of the United States. In support of this last point, see the quotation of Chirac below on the most recent European achievement:

The Euro is first and foremost the fruit of your efforts and your success. It is also the expression of your lucidity and of your open mind. It will bring us more stability in an uncertain world and more power against the great economic and political poles developing on the planet. [L'Euro, c'est d'abord le fruit de vos efforts et de vos succès. C'est aussi l'expression de votre lucidité et de votre esprit d'ouverture. [...] il nous apportera plus de stabilité dans un monde incertain. Plus de force face aux grands pôles économiques et politiques qui se développent sur la planète] (1998, par. 5).

\section{Emotion and nationalism}

Earlier we suggested that emotion is one of the most important foundations of national identity and nationalism. For the speeches under investigation, this emotional dimension is mainly founded on French values, and on the 'myth of France'. To an outsider these could easily appear as hazy notions, be it for the simple fact that they are referred to as selfevident. By the 'myth of France' we understand the idea that up until today the French community is imbued with the intellectual and moral assets of the French Revolution. The values 'liberty, equality, and fraternity', and values of the 'Enlightenment' are constantly called to mind, be it implicitly because they are self-explanatory. They are assumed to be familiar to every Frenchman, and to form a natural and primary part of their mental stock-in-trade as the tacit knowledge of the French community.

Subsequently, De Gaulle starts to turn to these values to the 'grandeur' of his country, and thus the emotional, impalpable qualities of his nation, to justify his decisions and his battle against the two superpowers. The emotional component then disappears into the background with Pompidou, to resume its position with Giscard d'Estaing. He likes to speak of his people as a great people, but very often fails to elucidate why. In this way he seems to mystify France, by a single reference to French values. Next, Mitterrand does not have much attention for this element and would rather stick to the point. Chirac's nationalism is substantiated by concrete facts as well as by the instinctive myth of the French nation.

As to our second research question, we found that prominence of nationalism paralleled the weight of emotional charge in the speeches. 


\begin{tabular}{|c|c|c|}
\hline \multicolumn{3}{|c|}{ Nationalism } \\
\hline & Orientation & Emotional charge (+/-) \\
\hline De Gaulle & $\begin{array}{l}\text { international: } \\
\text { influence \& autonomy }\end{array}$ & $+:$ myth \\
\hline Pompidou & national: prosperity & -: materialistic/concrete \\
\hline Giscard d'Estaing & national: people & $+:$ myth \\
\hline Mitterrand & $\begin{array}{l}\text { international: } \\
\text { influence \& autonomy }\end{array}$ & -: down-to-earth/concrete \\
\hline Chirac & $\begin{array}{l}\text { national \& international: } \\
\text { people \& openness (a. o.) }\end{array}$ & $+:$ myth \\
\hline
\end{tabular}

Figure 6. Orientation of nationalism and emotional charge in speeches of French presidents.

On top of the chart of nationalism we first encounter De Gaulle, followed by Chirac. Subsequently, Giscard d'Estaing and Mitterrand share a third position and at the bottom we find President Pompidou. Mainly the three first-mentioned presidents employ the emotionally appealing power of the nation. Figure 6 represents the nature of the emotional charge, and the orientation of the nationalism of subsequent French presidents.

\section{Frames and national identity/nationalism}

Among all the possibilities to find an entry into the issue of national identity (see Figure 1), certain structures of knowledge, sentiment or symbolic meaning can be unraveled that most strongly typify 'the French experience' according to the leaders of the nation. Underneath the themes we found three recurring structures of meaning that may encourage the French to experience a deep love for their nation.

First, we found that 'a sense of belonging' was prominent, be it in a specific form. The presidents attempt to convince the French of their natural mutual connection by stressing the safety they experience in their country. They are referred to as children of a fatherland, 'la Patrie'. 'La Patrie' is presented as an acting creature that would go through hell for 
his inhabitants as a father for his children. Loyalty is expected in return. Now and again a president embodies the fatherland and turns himself into a father figure: The president as a national cultural symbol. A sense of belonging in terms of the 'bond of safety' between the French and their nation may be distinguished as the first deeper meaning structure or frame contained in the speeches. Although this structure emerges in the discourses of each president, it establishes itself particularly well in three presidents: De Gaulle, Mitterand, and Chirac. See an example of De Gaulle's style below:

Of course, that is how it is and whatever happens, France will protect its children, persons and their goods, whatever their origin, just as it will safeguard the interests that are theirs. [Bien entendu et quoi qu'il arrive, la France protègera ses enfants dans leur personne et dans leurs biens, quelle que soit leur origine, tout comme elle sauvegarde les intérêts qui sont les siens] (1960, par. 6).

De Gaulle not only calls upon 'la Patrie' as protector of the people, as in this example, but he often presents himself as an extension of the respected homeland. Mitterrand is far more modest and, contrary to De Gaulle, he never elevates the presidency to the level of the nation. The following quotation shows his idea of France as a family:

But I still hear a word my father continually took into his mouth: "Tolerance". "Be tolerant amongst yourselves", he said to our turbulent little squad. Well, dear compatriots, a country is like a family. One does not have the same tastes, one does not have the same ideas, but one shares the same fatherland. Ours is beautiful and great. Let us help it; let us serve it. Let us love our fatherland. [Mais j'entends encore un mot qui revenait constamment dans la bouche de mon père: "Tolérance". "Soyez tolérants entre vous", disait-il à notre petite troupe turbulente. Eh bien! Mes chers compatriotes, un pays est comme une famille. On n'a pas les mêmes goûts, on n'a pas les mêmes idées, mais on a la même Patrie. La notre est belle et grande. Aidonsla, servons-la. Aimons notre Patrie] (1984, par. 2).

Chirac inclines towards another direction. Though he does not attribute the same spiritual qualities to the presidency as De Gaulle did, he continuously tries to convince the people of his qualities as guardian of France and the French, as becomes apparent through the following fragment:

While safeguarding the continuity of the State, I'm also the guardian of the values of the republic, in the first place liberty and solidarity. 
Being responsible for the nation's future, I will intervene each time its interests are at stake to tell you what I consider beneficial for the French, or on the contrary, dangerous for France. [Garant de la continuité de l'Etat, je suis aussi le gardien des valeurs de la République, au premier rang desquelles la liberté et la solidarité. Responsable de l'avenir de la nation, j'interviendrai chaque fois que ses intérêts seront en jeu pour vous dire ce que je crois être bon pour les Français ou, au contraire, dangereux pour la France] (1997, par. 2).

The second frame we found consists of the 'great French values'; i.e., the primary shared cultural knowledge of the French that makes them blood relatives, or at least spiritual kin. The speeches are practically inconceivable without these values, which should be honored at all times, because of their potential to save humanity worldwide. We found that their use is twofold: On the one hand they are a plea for the fact that France is a home for its people. Chirac gives a nice example of this:

We have certain values in common. [...] The necessity of solidarity. A more responsible solidarity where everyone works to fulfill their part of the contract. [...] The desire to be useful, [...] Tolerance, which does not mean abandonment of one's convictions, but respect for the other. The republican spirit and a sense of the common interest. [...] Let us maintain these demands. Let us maintain these values. By keeping them alive, we will stand stronger in facing the times to come. [Nous avons en commun certaines valeurs. [...] L'exigence de solidarité. Une solidarité plus responsable ou chacun s'efforcerait de prendre sa part du contrat. [...] Le désir d'être utile, [...] La tolérance, qui ne doit pas être renoncement a ses convictions, mais respect de l'autre. L'esprit républicain et le sens de l'intérêt général. [...] Gardons ces exigences. Gardons ces valeurs. En les faisant vivre, nous serons plus forts pour aborder les temps qui viennent] (1999, par. 8).

On the other hand, they are a plea to extend the influence of France throughout the world, as France still has a beneficial influence to offer the world. Manifestation of this second structure of meaning is most striking in Giscard d'Estaing and Chirac and in their belief in France's global vocation, as shown in the illustration below, of, first, Giscard's belief in French diplomacy:

I wish that in 1979, France would make its message of peace, freedom and fraternity radiate across the world. [...] Everywhere, I try to affirm the image of France, of a country with an open attitude towards the 
evolution of the world, independent and proud, but fraternal, active but respectful of the freedom and dignity of others. [Je souhaite qu'en 1979, la France fasse rayonner son message de paix, de liberté et de fraternité dans le monde. [...] Partout, je m'efforce d'affirmer l'image de la France, celle d'un pays ouvert sur l'évolution du monde, indépendant et fier mais fraternel, actif mais respectueux de la liberté et de la dignité des autres] (1978, par. 4).

And secondly, in an illustration of Chirac's optimism regarding the role of France in the process of globalization:

We have also chosen to participate in globalization, to go all the way in playing our part. But a controlled, organized globalization with respect for its environment that is capable of taking into account the aspirations of men and of diminishing poverty. That will be the complete meaning of the battle of France in the major negotiations to come. [Nous avons choisi aussi de prendre part à la mondialisation, d'en prendre toute notre part. Mais une mondialisation maîtrisée, organisée, respectueuse de l'environnement, capable de prendre en compte les aspirations des hommes et capable de faire reculer la pauvreté. Ce sera tout le sens du combat de la France dans les grandes négociations à venir] (1999, par. 6).

The third frame comprises the general idea of the (significant) others. We already explained the dialectical relationship between subjects of a nation and the 'Other' in the construction of national identity. One discovers ones own identity once the other has been identified. We recognized the frame of the 'Other' in several different ways in the speeches: At times as a threat that has to be defeated, or as a competitor over whom a victory has to be won. First of all, we examine below quotations first by De Gaulle and then Mitterrand, who are on the same page where the enemy/'other' is concerned:

This is how the ambitions of the Soviet system, the commotion it causes to everything on earth that is inclined towards disorder and hatred, [...] without abandoning its cause that is called totalitarianism, all of that compels us to be vigilant, to anticipate in our defense, and to maintain difficult alliances. [C'est ainsi que les ambitions du système soviétique, les excitations qu'il prodigue à tout ce qui, sur la terre, tend au désordre et à la haine, [...] sans renoncer à leur cause qui s'appelle le totalitarisme, tout cela nous oblige à nous mettre en garde, à pourvoir à notre défense, et à maintenir des alliances difficiles] (1961, par. 3). 
and:

Anyway, we will personally take care of our security and independence. That is why I have ordered - every policy is a choice - to reinforce our means of dissuasion on which our national defense is based. But since I used the word security, I would like to specify that it applies just as well to the interior as to the exterior; any compromise is impossible once the national community is at stake (1982, par. 8).

[Quoi qu'il en soit, nous ne laisserons a personne le soin d'assurer a notre sécurité et notre indépendance. Aussi ai-je donné l'ordre - toute politique est un choix - de renforcer nos moyens de dissuasion sur lesquels repose la défense du pays. Mais puisque j'ai prononcé le mot sécurité, je précise qu'il s'applique aussi bien à l'intérieur qu'à l'extérieur, il n'est pas de compromis quand la communauté nationale est en cause].

Both discern a real threat from abroad, which justifies their choice to devote more funds to defensive warfare. This frame fulfills a central task mainly in the discourses of De Gaulle and Mitterrand, especially in their battle against the superpowers. Nevertheless, Pompidou reserves an important role for the 'other' as well. It seems as if nothing is as important for him as engaging in the economic, technical, and social battle with foreign competitors and most of all, winning it.

Nobody can deny at this moment that growth in France is the most important in Europe. Nobody can deny [...] that right now, France is the country in the world that makes the largest effort in favor of housing. [Personne ne peut nier que l'expansion soit en France, et l'heure actuelle, la première d'Europe. Personne ne peut nier [...] que la France soit, à l'heure actuelle, le pays au monde qui fait le plus gros effort en faveur du logement] (1972, par. 1).

In view of globalization, it is simply impossible for Chirac to ignore the outside world. It grabs his attention in two different ways. He welcomes a constructive cooperation. But then again, in reaction to this new openness, he stresses that he will be on his guard to prevent any strange influences to dominate French culture. This is an abstract way to make the 'other' omnipresent. He exemplifies this double-faced attitude towards the world below, in this case towards Europe:

More than ever Europe is indispensable to us. It is a guarantee for peace. France wants to play an entire part in it. I will see to it that 
the European Union is more attentive to your daily preoccupations, that it will be more responsive to your social aspirations, that employment will be made a priority. [L'Europe nous est plus nécessaire que jamais. Elle nous garantit la paix. La France veut y prendre toute sa place. Je veillerai à ce que l'Union Européenne soit plus attentive à vos préoccupations quotidiennes, à ce qu'elle réponde davantage à vos aspirations sociales, à ce qu'elle fasse de l'emploi une priorité] (1995, par. 10).

\section{Discussion}

We have sought to build a conceptual bridge between the phenomena of national identity and nationalism, and to embody it in a coding instrument. Our analysis not only recognizes that both concepts have different connotations, but also captures them in their mutual relation. We therefore considered national identity both as an ideal and instrument of nationalism, and also as a product of nationalism. We discovered three criteria that can be used to determine when utterances cross from the field of neutral national identity into the normative domain of nationalism. Moreover, literature shows that the barely substantial nature of nationalism and national identity is caused by its unquestionable affective charge. This would make it virtually impossible to fit into a theory and empirical coding instrument. Attempts to do so, then, are hard to find. Our research represents a first attempt to recognize this emotional dimension by incorporating it systematically in our observations and analysis (see also Van Noije, 2001).

In answering three related research questions we were able to link individual discursive constructions of national identity and/or nationalism of five presidents to three overarching structures of meaning or frames: The bond of safety, the great French values, and significant others. These frames illustrate how five French post-war presidents in their New Year's speeches appealed to national sentiments of the people. The notion of the 'other' is a product of our analysis that we consequently and systematically tested on the whole corpus of speeches. It appeared to be of central importance, as it emerged with every president, though we showed that its interpretation varies. The fact that we gained this result in a country whose borders have never been at stake at any time during the period under examination, leads us to the conclusion that the 'other' is indeed a condition for the dynamic process of national identity as well as nationalism. Our decision to add this element to the definition of national identity thus turned out to be of considerable value. 
As we are aware of the limited scope of our analysis, we would like to make a final comment on the validity of our findings. The frames we discovered find substantive support in theoretical notions proposed by De Swaan (1995) and Hall (1992). In a historical perspective, De Swaan contends that social identifications should be conceptualized as both a cognitive and emotional process. Affective abstract identifications, such as national identity, nowadays still rely on primary group relationships of kinship and geographical proximity (1995: 32). National identity is activated once emotions, provoked by the imagination of a family member or neighbor in danger, come into play. According to De Swaan, imagination and symbolization are of key importance, because group relations nowadays are far more complex and abstract. That is, the bond or identification with compatriots no longer relies on actual kinship. Nevertheless, the experience of collective problems and collective goals still presumes and even requires reciprocal identification. Therefore, national identification is a condition for common goals and unity, which must be kept alive by stressing relations of kinship and physical closeness, for instance by political leaders in their speeches.

We think this is the essence behind the many references we found to protection and unity, and to the frame of the bond of safety. Following the idea elaborated above, the presidents would play on primary group identifications by referring to 'la Patrie' and themselves as a father, and the French as their children, as part of one extended family. Likewise, the constant glorification of French values, our second frame, seems logical from this point of view. The French revolution, the Enlightenment, as proof of French moral superiority, penetrated the blood of the French and of nobody else but the French and those within the borders of the territory, which, by the way, adds an image of extended proximity. Hall (1992), like De Swaan, stresses the importance of an imagined shared past and common destiny to evoke national identifications. The imagined community, thus created, relies on 'narrating the nation' (Hall, 1992: 292), of which the central element is the emphasis on origin, continuity, traditions, and timelessness. In this frame of reference, the essence of the national character, in our case the great French values, remains unchanged through all the vicissitudes of history. It is presented as simply being there from birth, invariable, and eternal. As an example, Hall refers to Mrs. Thatcher, at the time of the Falklands War (294), whose words bear a striking resemblance to the expressions of French presidents in their attempt to revive national identity and nationalism. In the light of our analysis, this could be more than a coincidence. Our third frame, the significant other, complies with the general dialectic of inclusion and exclusion in the course of group formations, as described by De Swaan (1995). Perceived similarities and differences in a situation of 
competition provide a basis for affective involvement or detachment. Threats must be imagined to mobilize the mechanism of identification (35), wrongdoers, and rivalry. In our case the superpowers mobilize the dialectics of national identification and make the indefinable Frenchhood tangible. To this we can add the conclusion that our analysis showed that the French presidents sensed the specific importance of primary identifications for the establishment of a bond in creating a collective front against the 'other' that is excluded from this alliance. The appeal to these frames, as basic conditions for national awareness, and more specifically the appeal to primary group identifications may imply that our results might be more universally applicable than our corpus of five post-war French presidents can substantiate. Comparative analysis of other contexts and other countries could shed more light on this question.

\section{Notes}

1. Lonneke Van Noije has an MA in French, and has translated all of the French speeches and literature used in this investigation.

2. The seven speeches by Mitterand in his second term (1988-1995) were not included. In spite of several attempts these turned out to be irretrievable. Evidently this affects the continuity of the data, but still is hardly detrimental to the sample as seven speeches remain to be analyzed.

3. The New Year's speeches of De Gaulle up to and including those of Mitterand derive from a thesis by Finniss-Boursin (1992). Those of current president Chirac were obtained from the Internet.

4. The speeches of Mitterand are not complete, but the amount (seven) is comparable to three other presidents. We analyzed all six speeches by Chirac, all seven speeches by Giscard d'Estaing, and, because of his untimely death Pompidou has only produced five speeches. General De Gaulle stands out with eleven speeches.

5. The number of paragraphs for each president in chronological order is: 96, 29, 44, 47 , and 55 .

6. The numbers refer to the actual paragraph of the speech.

\section{References}

Chaunu, P. (1982). La France: Histoire de la sensibilité des Français a la France. Paris: Laffont.

Chirac, J. (1995-2000). Discours de Monsieur Jacques Chirac. Available at: http:// www.elysee.fr/cgibin/aura ...r file=discours/1995 (etc) VOEUX96 (etc.).html

Cillia, R. de, Reisigl, M., and Wodak, R. (1999). The discursive construction of national identities. Discourse and Society, 10(2), 149-173.

Connor, W. (1978). A nation is a nation, is a state, is an ethnic group, is a .... Ethnic and Racial Studies, 1(4), 377-400.

Elgie, R. and Griggs, S. (2000). French politics: Debates and controversies. London: Routledge.

Entman, R. M. (1993). Framing: Toward clarification of a fractured paradigm. Journal of Communication, 43(4), 51-58. 


\section{4}

Lonneke van Noije and Ellen Hijmans

Finniss-Boursin, F. (1992). Les discours de vœux des Présidents de la République: La France au fond des yeux. Paris: Librairie Générale de droit et de jurisprudence.

Glaser, B. and Strauss, A. (1969). The discovery of grounded theory. Chicago, IL: Aldine.

Hall, S. (1992). The question of cultural identity. In S. Hall, D. Held, and T. McGrew (Eds.), Modernity and its futures (pp. 274-325). Cambridge: Polity Press.

Hijmans, E. (1996). The logic of qualitative media content analysis: A typology. Communications, 21, 93-108.

Hijmans, E. (2003). Het dynamisch identiteitsmodel. Een synthese van benaderingen [The dynamic identity model. A synthesis of approaches]. In T. Hak and F. Wester (Eds.), Kwalitatief onderzoek: De praktijk. Waarneming, analyse en reflectie (pp. 114-126). Amsterdam: SISWO.

Krippendorff, K. (1980). Content Analysis: An introduction to its methodology. Newbury Park, CA: Sage.

Mead, G. H. (1934). Mind, self and society. Chicago, IL: University of Chicago Press.

Meyer, H. and Geschiere, P. (1999). Globalisation and identity: Dialectics of flow and closure. Oxford: Blackwell.

Noije, L. van (2001). Nationale gevoelens: Een wens voor het nieuwe jaar [National feelings: A New Year's wish]. Unpublished Master's Thesis, Department of Communication, University of Nijmegen, The Netherlands.

Schiller, H. (1969). Mass communications and American empire. New York: Kelley.

Schlesinger, Ph. (1991). Media, state and nation. London: Sage.

Smith, A. (1991). National identity. London: Penguin.

Swaan, A. de (1995). Widening circles of identification: Emotional concerns in sociogenetic perspective. Theory, Culture and Society, 12, 25-39.

Triandafyllidou, A. (1998). National identity and the 'other'. Ethnic and Racial Studies, 21(4), 593-612. 